\title{
Terrace springs: habitat haven for macrobenthic fauna in the lower plain of the River Ticino (Lombardy, Northern Italy)
}

\author{
Renato Sconfietti, India Pesci, Daniele Paganelli*
}

\begin{abstract}
Springs are important environments between hypogean and epigean habitats; the interaction between aquatic and terrestrial ecosystems is an important factor for their biotic communities. We investigated the ecology of the macrobenthic community of two lowland springs in the River Ticino valley, focusing on the autoecology of some relevant species and on the role of springs as hotspots of biodiversity in an area threatened by anthropogenic pressure.

We collected 26 taxa in total: diptera (8), trichoptera (6), gastropods (5), coleoptera (2), crustacea (2), lumbricidae (1), odonata (1), plathelminthes (1). Some of them are stenothermal and oligotrophic species thus quite unusual for a flood plain area characterized by intensive agricultural activities.

In conclusion, our study highlights the importance of lowland springs in conserving some habitat-selective macrobenthic species.
\end{abstract}

Key words: lowland springs, fluvial terrace, insular biotopes, crenic assemblages.

Riassunto - Sorgenti di terrazzo: un rifugio per la fauna macrobentonica nella bassa pianura del Ticino (Lombardia, Nord Italia).

Le sorgenti sono ambienti importanti tra habitat ipogei ed epigei; 1'interazione tra ecosistemi acquatici e terrestri è un fattore importante per le loro comunità biotiche. Abbiamo studiato l'ecologia della comunità macrobentonica di due sorgenti di pianura nella valle del Ticino, concentrandosi sull'autoecologia di alcune specie rilevanti e sul ruolo delle sorgenti come punti caldi della biodiversità in un'area minacciata dalla pressione antropogenica.

Abbiamo raccolto 26 taxa in totale: ditteri (8), tricotteri (6), gasteropodi (5), coleotteri (2), crostacei (2), lumbricidi (1), odonata (1), platelminti (1). Alcuni di essi sono specie stenoterme e oligotrofe quindi piuttosto inusuali per una zona di pianura alluvionale caratterizzata da attività agricole intensive.

In conclusione, il nostro studio evidenzia l'importanza delle sorgenti di pianura nella conservazione di alcune specie macrobentoniche selettive dell'habitat.

Parole chiave: sorgenti di pianura, terrazza fluviale, biotopi insulari, assemblaggi crenici.

Department of Earth and Environmental Sciences, University of Pavia, Via S. Epifanio 14, 27100 Pavia, Italia

* Corresponding author: daniele.paganelli@unipv.it

(C) 2018 Renato Sconfietti, India Pesci, Daniele Paganelli

Received: 29 October 2017

Accepted for publication: 13 February 2018

\section{INTRODUCTION}

Springs are important environments between hypogean and epigean habitats (Hanh, 2000; Smith et al., 2003) and, despite their limited dimensions, they are composed of various microhabitats and are often characterized by high biodiversity (Weigand, 1998; Cantonati et al., 2012). The interaction between aquatic and terrestrial ecosystems is important for the structure of spring habitat: shading by riparian vegetation can affect levels of autochthonous and allochthonous organic matter (Barquín \& Scarsbrook, 2008) and it can also influence the temperature of spring water consequently extending habitats for cold stenothermic species (Roca \& Baltanas, 1993).

In general, these biotopes are classified according to a method based on current velocity, which was developed by Steinmann (1915) and Thienemann (1922). Recently, Martin \& Brunke (2012) suggested the term rheo-elocrene to classify an intermediate type of spring, which are often found on terraces, characterized by a thin film of water flowing constantly through canopy areas, with sandy fine gravel substrata (Gerecke, 1991). These habitats are also typical of forested areas with an elevated level of woody debris, leaves and mosses on the bottom (Cantonati \& Bonettini, 1995; Di Sabatino et al., 2003).

Several studies have supported the importance of abiotic factors in determining the composition of the fauna and flora in springs (Erman \& Erman, 1995; Hanh, 2000; Smith et al., 2003). Nevertheless, one of the main characteristics that influence the compositions of spring communities is the cold stable water temperature (Illies, 1952; Erman \& Erman, 1995).

In Europe, lowland eucrenic habitats were often subject of various studies (Zollhöfer et al., 2000; Gerecke \& Franz, 2006; Von Fumetti et al., 2006; Ilmonen et al., 2009; Von Fumetti \& Nagen, 2012). In Italy, instead, researchers have mainly studied north-eastern Alpine and preAlpine springs (Crema et al., 1996; Gerecke et al., 1998; Stoch \& Tomasin, 2002; Mezzanotte \& Sambugar, 2004; Cantonati et al., 2006; Sambugar et al., 2006) or central and southern Apennine areas (Galassi, 1997; Cianficconi et al., 1998; Di Sabatino et al., 2003; Bottazzi et al., 2008) while lowland springs have been neglected, apart from a few studies on plain-springs and resurgence springs (Girod, 1965; Cotta-Ramusino et al., 1991; Cianficconi et al., 1998; Crosa \& Buffagni, 2002) and qualitative studies on 
river springs of the Ticino valley (Sconfietti et al., 2009a; Pesci, 2010). These types of microhabitats were mainly investigated for water chemistry in relation to agricultural impact and meiofauna (Gerecke et al., 1998; Laini et al., 2011).

Therefore, the present study addresses the benthic community of two springs of the River Ticino valley (River Po plain, North of Italy), focusing on the autoecology of some relevant species and on the role of springs as hotspots of biodiversity in an area threatened by anthropogenic pressure.

\section{METHODS}

\section{Study area}

The River Ticino is one of the most important tributaries of the River Po and its Italian course is recognized as a regional park and is protected by UNESCO. The lower flood plain is characterized by intensive agricultural activities and high anthropogenic pressure, however numerous semi-natural areas are present (Sconfietti et al., 2009b).

The study area is situated near the city of Pavia (SouthEast Lombardy, Northern Italy), a few kilometres upstream from the River Po confluence (Fig. 1). It is located on the left side of the floodplain, along the scarp of the fluvial terrace covered by a shady forested zone, characterized by the dominance of the allochtonous species Robinia pseudoacacia L. and a thick underwood with Robus caesius L. and highly hygrophilous species, such as Equisetum telmateia L., E. arvensis L. and mosses.

Where the slope of the terrace shows a marked stair step, many permanent hydric emergences seep out from a perched aquifer, about 8 metres below the upper level of the alluvial plain, almost at the same level as the lower level of the floodplain. These water streaks converge in a few small streams, which slowly flow towards a narrow water course called Vernavola Stream. The springs are 50-100 cm wide and 20-25 m long and they have a weak discharge of less than $10 \mathrm{l} \mathrm{m}^{-1}$ and a water speed of 20 $\mathrm{cm} \mathrm{s}^{-1}$. Their substrate is mainly composed of fine gravel,

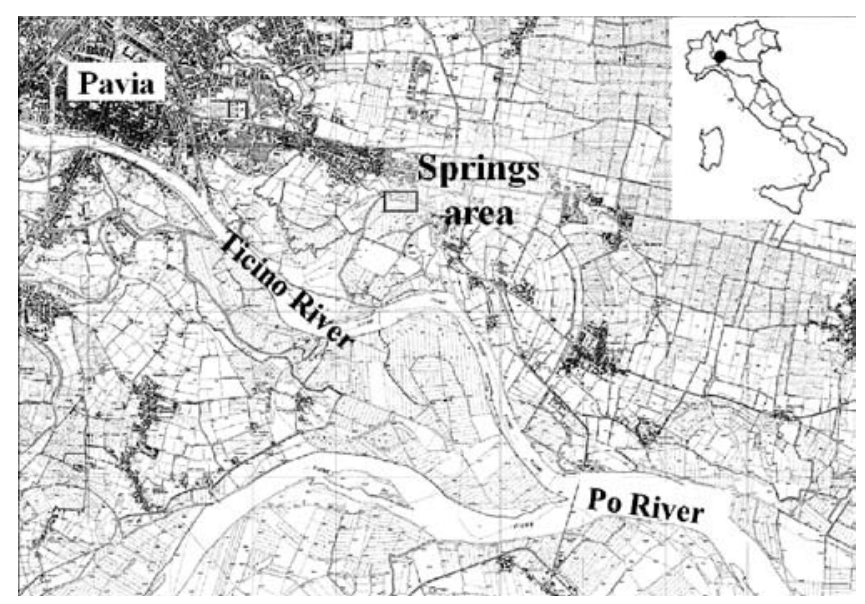

Fig. 1 - Study area. sand and clay; the bottom is also rich in vegetal detritus. Nitrate concentration in their waters is known to range from $10 \mathrm{mg} \mathrm{l}^{-1}$ to $13 \mathrm{mg} \mathrm{l}^{-1}$ (Pesci, 2010).

A few species of aquatic or semi-aquatic plants were present in the spring brooks: Lemna minor L., Ranunculus ficaria L. and Nasturtium officinale L. We also found a large population of Leucojum aestivum L., a threatened protected species by the Habitat Directive 92/43 CEE.

\section{Sample collection and data analyses}

From April 2008 to March 2009, we monthly collected the macrobenthic community in two permanent terrace springs (hereafter called S1 and S2). In order to perform quantitative sampling and due to the small dimension of the springs, we used a small hand-net $(950 \mu$ mesh) with an additional aluminium frame $(19.2 \times 8.7 \mathrm{~cm})$, placing the hand-net on the ground and gently moving the substrate within the aluminium frame. For all samples, we collected three replicates to cover an area of $500 \mathrm{~cm}^{2}$.

Temperature was recorded using a digital thermometer DELTA OHM HD 8705, and dissolved oxygen was measured using an Idronaut Oxyliquid Oximeter probe.

Macrobenthos was sorted, identified and counted in the laboratory using a stereo microscope at 10-40x magnification, and preserved in $70 \%$ ethanol. We identified to species level crustacea, platyhelminthes, trichoptera, odonata, lumbricidae and coleoptera; diptera and all other taxa were identified to genus or family level.

In order to compare the macrobenthic communities of the two springs and seasonal effects on the biotic assemblages, we performed an ANOSIM test on log transformed data and moreover, a SIMPER analysis was performed in order to define the most dominant species in each spring. Finally, a cluster analysis (using species as response variable) was carried out with the aim of highlighting the ecological affinity between macrobenthic species.

All the statistical analyses were performed using PRIMER 5.0 software package (Clarke and Warwick, 1994).

\section{RESULTS}

In $\mathrm{S} 1$, the water temperature varied from $11^{\circ} \mathrm{C}$ to $18.5^{\circ} \mathrm{C}$, while in $\mathrm{S} 2$ it varied from $18.7^{\circ} \mathrm{C}$ to $9.8^{\circ} \mathrm{C}$. Moreover, the oxygen saturation reached $90 \%$ in $\mathrm{S} 1$ and $94 \%$ in $\mathrm{S} 2$.

Considering the biotic data, we collected 26 taxa in total: 15 were identified to species level while 6 to genus level. In total, we identified: diptera (8), trichoptera (6), gastropods (5), coleoptera (2), crustacea (2), lumbricidae (1), odonata (1), plathelminthes (1) (Tab. 1).

The community in $\mathrm{S} 1$ reached a density of about 4000 ind. $\mathrm{m}^{-2}$ while in $\mathrm{S} 2$ it had density of 2375 ind. $\mathrm{m}^{-2}$. This difference was confirmed by the ANOSIM test $(\mathrm{R}=0.38$, $\mathrm{p}<0.05)$; at the contrary, no statistical difference was recorded between seasons $(\mathrm{S} 1, \mathrm{R}=-0.019, \mathrm{p}>0.05 ; \mathrm{S} 2, \mathrm{R}=-$ $0.019, \mathrm{p}>0.05$ ).

Furthermore, SIMPER analysis showed that the community of S1 was mainly characterized by the presence of the amphipod Echinogammarus stammeri, the planarian Polycelis felina and the caddisfly Crunoecia irrorata. 
Tab. 1 - Taxa collected in spring S1 and S2.

\begin{tabular}{|c|c|c|c|c|}
\hline Group & Taxon & Author's name & S1 & S2 \\
\hline \multirow[t]{2}{*}{ Crustacea } & Echinogammarus stammeri & (Karaman, 1931) & $\mathbf{X}$ & $\mathbf{X}$ \\
\hline & Androniscus dentiger & Verhoeff, 1908 & $\mathbf{X}$ & $\mathbf{X}$ \\
\hline \multirow[t]{5}{*}{ Gastropoda } & Bythinella schmidti & (Küster, 1852) & $\mathbf{X}$ & $\mathbf{X}$ \\
\hline & Gyraulus crista & (Linnaeus, 1758) & $\mathbf{X}$ & $\mathbf{X}$ \\
\hline & Gyraulus laevis & (Alder, 1838) & $\mathbf{X}$ & $\mathbf{X}$ \\
\hline & Lymnaea sp. & & $\mathbf{X}$ & $\mathbf{X}$ \\
\hline & Sadleriana sp. & (Küster, 1852) & $\mathbf{X}$ & \\
\hline \multirow[t]{2}{*}{ Coleoptera } & Macronychus quadrituberculatus & Ph. Müller, 1806 & $\mathbf{X}$ & $\mathbf{X}$ \\
\hline & Helodidae & & $\mathbf{X}$ & $\mathbf{X}$ \\
\hline \multirow[t]{8}{*}{ Diptera } & Dixa sp. & & $\mathbf{X}$ & $\mathbf{X}$ \\
\hline & Ceratopogonidae & & $\mathbf{X}$ & \\
\hline & Hexatoma sp. & & & $\mathbf{X}$ \\
\hline & Odontomia sp. & & $\mathbf{X}$ & $\mathbf{X}$ \\
\hline & Psycodidae & & $\mathbf{X}$ & $\mathbf{X}$ \\
\hline & Diamesinae & & $\mathbf{X}$ & $\mathbf{X}$ \\
\hline & Tanypodinae & & $\mathbf{X}$ & $\mathbf{X}$ \\
\hline & Tipula sp. & & & $\mathbf{X}$ \\
\hline Oligochaeta & Eiseniella tetraedra & (Savigny, 1826) & $\mathbf{X}$ & $\mathbf{X}$ \\
\hline Odonata & Cordulegaster boltonii & (Donovan, 1807) & & $\mathbf{X}$ \\
\hline \multirow[t]{6}{*}{ Trichoptera } & Crunoecia irrorata & (Curtis, 1834) & $\mathbf{X}$ & $\mathbf{X}$ \\
\hline & Ernodes articularis & (Pictet, 1834) & $\mathbf{X}$ & $\mathbf{X}$ \\
\hline & Helicopsyche sperata & McLachlan, 1876 & $\mathbf{X}$ & $\mathbf{X}$ \\
\hline & Philopotamus montanus & (Donovan, 1813) & & $\mathbf{X}$ \\
\hline & Silo nigricornis & (Pictet, 1834) & $\mathbf{X}$ & $\mathbf{X}$ \\
\hline & Wormaldia occipitalis & (Pictet, 1834) & $\mathbf{X}$ & $\mathbf{X}$ \\
\hline Planaria & Polycelis feline & (Dalyell, 1814) & $\mathbf{X}$ & $\mathbf{X}$ \\
\hline
\end{tabular}

Similarly, in S2, the most abundant species was E. stammeri, even though its density was lower compared to S1. Even here, C. irrorata was very abundant, as the dragonfly Cordulegaster boltonii, which at the contrary was absent in S1; finally, here $P$. felina was less frequent and abundant compare to $\mathrm{S} 1$.

Moreover, the performed analyses highlighted that the slight dissimilarity between these two communities was mainly due to the abundance of $P$. felina in $\mathrm{S} 1$ and the presence of $C$. boltonii in $\mathrm{S} 2$.
After this analysis, we compared the biotic data by means of a cluster analysis: in S1, twelve taxa (more than half of the total) have over $50 \%$ affinity and nine out of twelve were clustered with over $70 \%$ of similarity: Helicopsyche sperata, Ernodes articularis, Helodidae, Silo nigricornis, Crunoecia irrorata, Tanypodinae, Diamesinae, Polycelis felina and Echinogammarus stammeri (Fig. 2). In the dendogram of S2, six out of nine taxa were clustered with almost $70 \%$ affinity; when a seventh taxon, Polycelis felina, was added to the cluster, the affinity decreased to $45 \%$ (Fig. 3). 


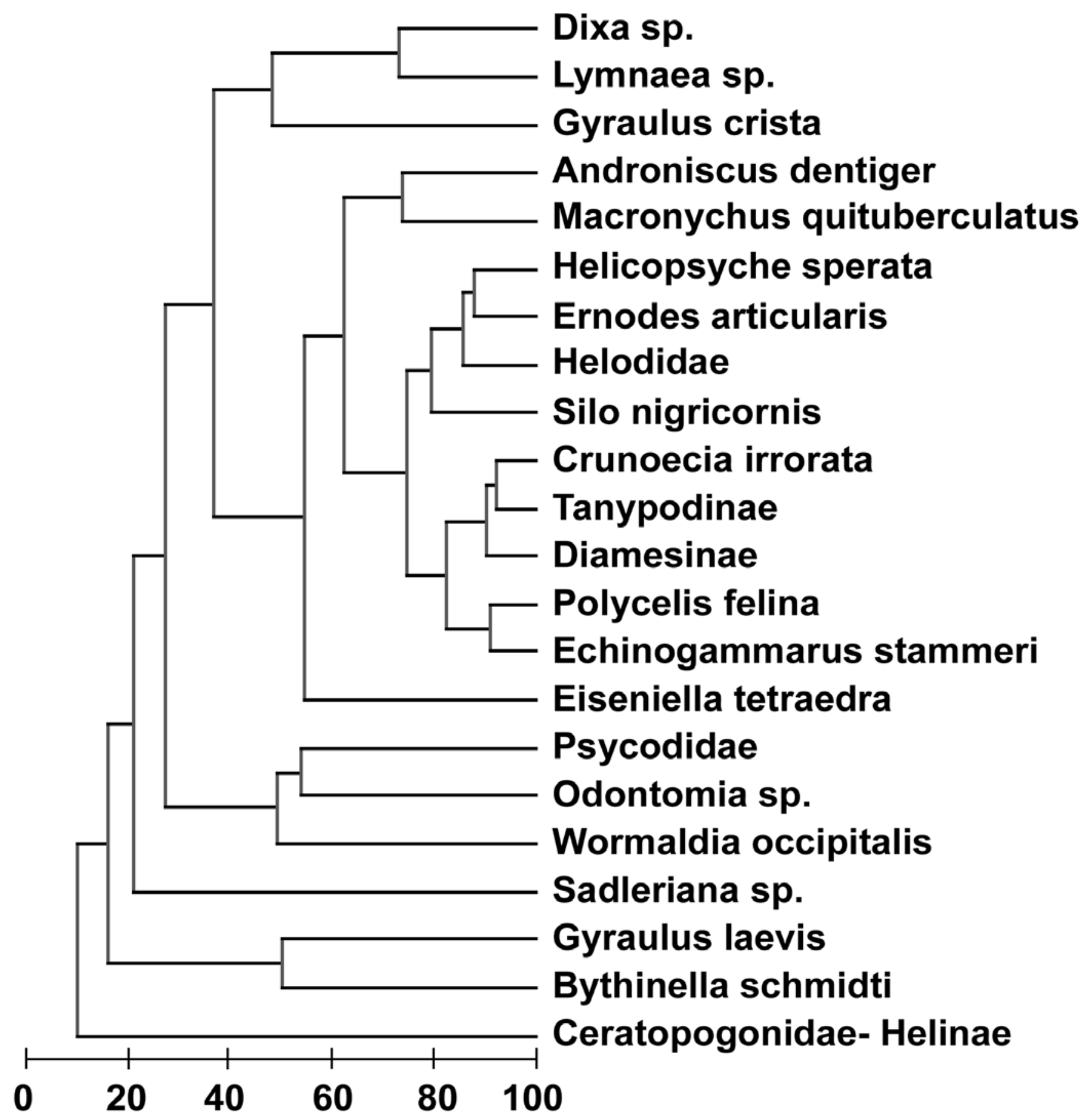

Fig. 2 - Cluster analysis of the macrobenthic community collected in Spring 1.

\section{DISCUSSION}

The annual investigation on two plain-springs of Northern Italy showed the absence of clear seasonality for the macroinvertebrate community, despite a marked seasonality of the water temperature. The temperature recorded in the investigated springs in the morning reached almost $20^{\circ} \mathrm{C}$ in the Summer, and presumably higher in the afternoon. At the same time, in Winter it never fell below $9^{\circ} \mathrm{C}$. The relatively high Summer temperature is due to the shallowness of the perched aquifer, which is only about 8 $m$ under the main level of the plain.
Water temperature is undoubtedly the most influential factor in crenal life, but the composition of spring communities also depends on a variety of other factors including habitat structures, microclimate, food and competition (Fisher, 1996). As well known, the presence of riparian vegetation is another important factor which governs the structure of the invertebrate communities in spring brooks: it is the principal resource of allochthonous matter and it has an important role in the trophic chain (Vannote et al., 1980).

In addition, the presence of bordering wet areas that never become dry between spring water is important 


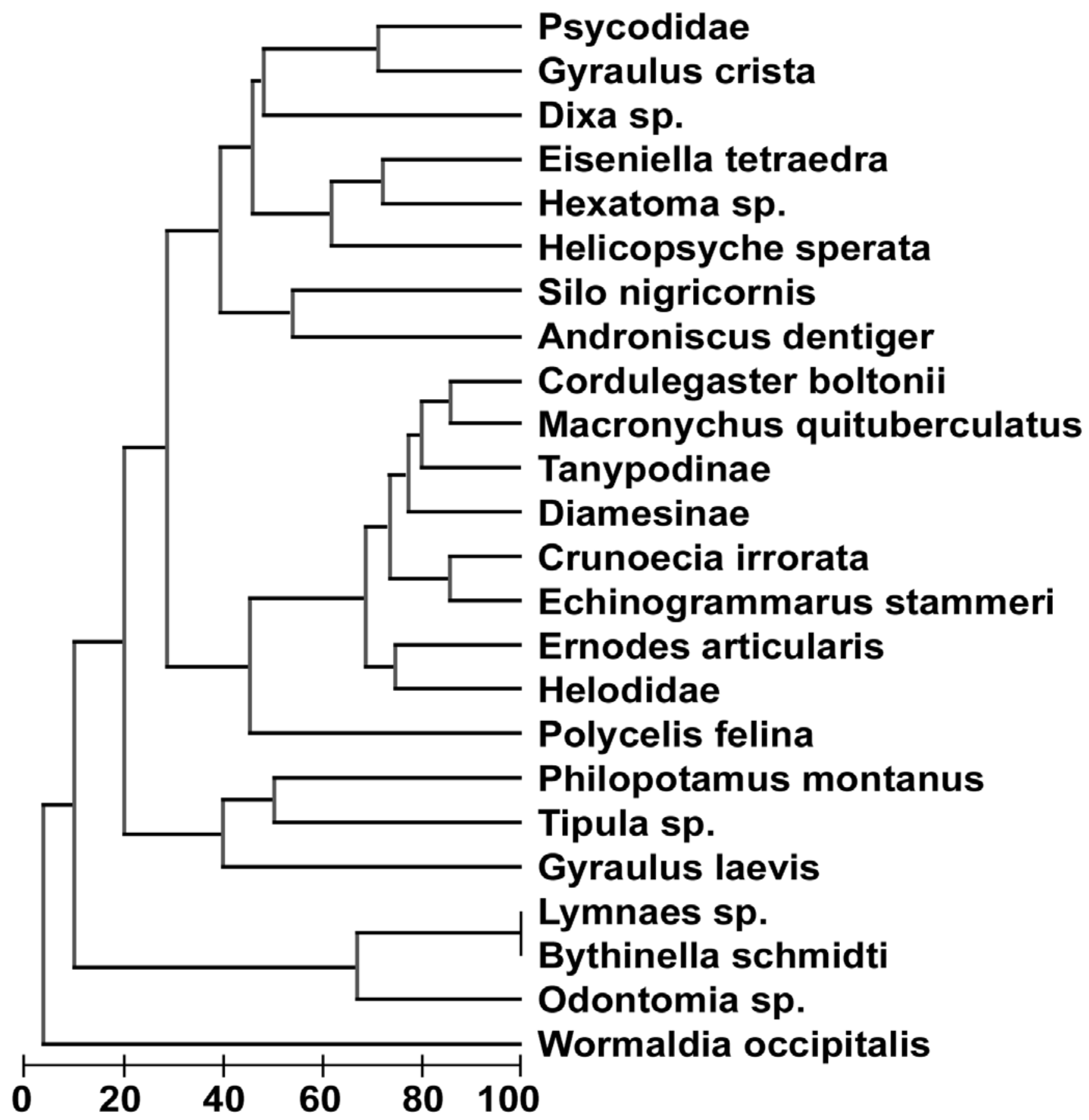

Fig. 3 - Cluster analysis of the macrobenthic community collected in Spring 2.

for the crenic community as also stated by Wagner et al. (1998).

The slight differences in species composition observed between the two springs can be attributed to two possible ecological explanations: the first hypothesis was related to a different granulometric composition of the bottom of the two studied springs while the second one could be related to a difference between the life-cycle of the taxa.

According to us, the first hypothesis should be the most relevant because, during our survey, we noticed that the bottom of S1 was mainly composed of gravels, a most suitable substrate for various species such as $\mathrm{Po}$ lycelis felina, Silo nigricornis and Helicopsyche sperata; on the contrary, the bottom of S2 was dominated by sand and clay, which instead facilitate the colonization of taxa typical of lentic water, such as the odonata Cordulegaster boltonii.

In the two studied springs, 10 out of 26 taxa collected showed a marked preference for spring specific habitat and they are known in literature as cold stenothermic species, associated to mountain springs with an annual temperature range from $3^{\circ} \mathrm{C}$ to $12^{\circ} \mathrm{C}$. 
Furthermore, we collected a high number of flies and caddisflies: high abundance of these groups is very common in lowland springs characterized by madicolous microhabitats (Cantonati et al., 2006).

Noteworthy is the constant presence and high abundance of the caddisflies Crunoecia irrorata, Philopotamus montanus, Ernodes articularis, Helicopsyche sperata and species belonging to the genera Wormaldia and Silo. As reported in literature, these species are less common in lowlands springs and their autoecology is strictly linked to springs and spring brooks surrounded by riparian forest, typical of crenic habitats (Moretti \& Viganò, 1959; Andree \& Timm, 1993; Laukötter, 1993; Cianficconi et al., 1998; Fischer et al., 1998; Hoffsten \& Malmqvist, 2000; Ilmonen \& Paasivirta, 2005; Smith et al., 2003; Buffagni et al., 2007).

The pool of the nine taxa highlighted by the similarity matrix and its cluster analysis was completed by Polycelis felina, one of the commonest freshwater planarian in cold and fast-water streams (Stoch, 2001). It is very frequent in rheocrenes springs that are characteristic of highly oxygenated or even oversaturated high-flow springs (Roca $e t$ al., 1992; Hanh, 2000).

The presence of stenothermal species is quite unusual for a flood plain area, and their presence highlights the role of springs as a refugee: the environmental characteristics of springs support a relatively rare fauna which can find refuge from disturbing events or extreme seasonal conditions (Di Sabatino et al., 2003; Maiolini et al., 2011).

Although less important from a quantitative point of view, other caddisflies (Philopotamus montanus, Wormaldia occipitalis) and few gastropods (Bythinella schmidti and Sadleriana sp.) show a marked habitat-specific preference for crenic conditions (Stoch, 2001; Wiberg-Larsen et al., 2000).

Other frequent species were the coleoptera Macronychus quadrituberculatus and the flies Odontomia sp.: both species that usually colonize rotten trees near small rivers or wetlands (Olmi, 1976; Campaioli et al., 1994).

Finally, it is also important to highlight the presence of two crustacean: the isopod Androniscus dentiger and the amphipod Echinogammarus stammeri. A. dentiger is mainly considered to be a troglophilous species, but it is also frequently found in the moss in ecotonal margins of springs and spring brooks (Harding \& Sutton, 1985; Latella \& Stoch, 2001); moreover, the high density of $E$. stammeri could be interpreted as a piece of evidence of a strong stability of the hydric emergence fed by the perched aquifer.

As indicated by Vannote et al. (1980), macrobenthic assemblages in springs are different from those in streams in the same geographic area. In accordance with this state and even though the studied terrace springs were very close to a semi-natural stream called Vernavola, between these two habitats there was not a direct connection, and this was also confirmed by the different composition of the two macrobenthic community. In the Vernavola Stream, the community was dominated by taxa very common in the lotic environments of the southern River Po plain with moderate/high anthropogenic impact such as the mayflies Baetis and Caenis, the caddisflies Hydrop- sychidae, the flies Chironomidae and Simuliidae, the dragonflies Calopterix and Onychogomphus (http://www.comune.pv.it/on/Home/Canalitematici/Ambienteeterritorio/ C.R.E.A.html).

\section{CONCLUSIONS}

Springs are important microhabitats in the riverine landscape (Ward \& Tockner, 2001; Lamberti et al., 2010; Ilmonen et al., 2012). According to Werum (2001), they can be defined as "water island" because they often show a marked disjunction from neighbouring streams. Furthermore, their community could be considered as a metacommunity because its scarce possibility to overcome barriers (Mac Arthur \& Wilson, 1963; 1967; Whittaker et al., 2001; Cantonati et al., 2012).

Our results confirm the important role of lowland springs as haven for some macrobenthic species: the community found in this study is composed of a set of species never been reported before in the nearby freshwater or wetland environments.

As described in the literature, the benthic assemblages of springs (mainly from mountain springs) are typically dominated by species which strictly colonize these particular types of aquatic environments. However, our study demonstrates that some of these stenoecious species can also colonise springs located in a flood plain composing a "mixed community" with other species commonly found in lowland freshwater environments.

Therefore, our data supports the hypothesis that these "spring species" are not as stenothermic and oligotrophic as usually reported in literature. In fact, our springs are characterised by high winter and summer temperatures and nitrate concentrations, due to the intensive agriculture activities and the superficial level of the aquifer.

In conclusion, considering this data, we hypothesize that the preference for springs of some species is probably more influenced by morpho-physical habitats, namely a thin layer of water, than by low temperature and low organic charge.

Furthermore, our study suggests how the spring habitat is peculiar and conservative, despite its heterogeneity in terms of ecological factors, including altitude, depth of the aquifer and, consequently, temperature.

The scarceness of studies on these habitats could be an incentive to continue investigations, in order to better define the auto-ecology of some species and to enrich the ecological database of these microhabitats.

\section{Acknowledgments}

This study is part of the Cariplo Foundation project "Hydraulical, biological and ecological characterization of the Vernavola Stream".

\section{REFERENCES}

Andree C. \& Timm T., 1993 - Die Quellen der Niederrheinischen Sandplatten. Crunoecia, 2: 39-63.

Barquín J. \& Scarsbrook M., 2008 - Management and conservation strategies for coldwater springs. Aquatic Conservation, 18: 580-591. 
Bottazzi E., Bruno M. C., Mazzini M., Pieri V. \& Rossetti G., 2008 - First report on Copepoda and Ostracoda (Crustacea) from northern Apenninic springs (N. Italy): a faunal and biogeographical account. Journal of Limnology, 67 (1): 56-63.

Campaioli S., Ghetti P. F., Minelli A. \& Ruffo S., 1994 Manuale per il riconoscimento dei macroinvertebrati delle acque dolci (Volume I-II). Provincia Autonoma di Trento.

Cantonati M. \& Bonettini A. M., 1995 - Ecomorfologia di sorgenti del Sarca nel Parco Adamello-Brenta (Trentino). Quaderni della Stazione Ecologica Civica Museo di Storia Naturale di Ferrara, 9: 345-351.

Cantonati M., Gerecke R. \& Bertuzzi E., 2006 - Springs of the Alps - sensitive ecosystems to environmental change: from biodiversity assessments to long-term studies. Hydrobiologia, 562: 59-96.

Cantonati M., Füreder L., Gerecke L., Jüttner I. \& Cox E. J., 2012 - Crenic habitats, hotspots for freshwater biodiversity conservation: toward an understanding of their ecology. Freshwater Science, 31 (2): 463480 .

Cianficconi F., Corallini C. \& Moretti G. P., 1998 Trichoptera fauna of the Italian springs. In: Studies in crenobiology. The biology of springs and springbrooks. Botosaneanu L. (ed.). Backhuys Publishers: 125-140.

Clarke K. R., 1993 - Non-parametric multivariate analyses of changes in community structure. Australian Journal of Ecology, 80: 117-143.

Clarke K. R. \& Warwick R. M., 1994 - Change in marine communities: an approach to statistical analysis and interpretation. Primer-E., Plymouth.

Cotta-Ramusino M., Crosa G. \& Buffagni A., 1991 - Microhabitat prefernces of benthic fauna (Ephemeroptera) in plain-springs (fontanili). Vrhandlungen des Internationalen Verein Limnologie, 24: 1626-1628.

Crema S., Ferrarese U., Golo D., Modena P., Sambugar B. \& Gerecke R., 1996 - Ricerche sulla fauna bentonica ed interstiziale di ambienti sorgentizi in area alpina e prealpina. Report Centro Ecologia Alpina.

Crosa G. \& Buffagni A., 2002 - Spatial and temporal niche overlap of two mayfly species (Ephemeroptera): the role of substratum roughness and body size. Hydrobiologia, 474: 107-115.

Di Sabatino A., Cicolani B. \& Gerecke R., 2003 - Biodiversity and distribution of water mites (Acari, Hydrachnidia) in spring habitats. Freshwater Biology, 48: 2163-2173.

Erman N. A., 2002 - Lessons from a Long-term Study of Springs and Spring Invertebrates (Sierra Nevada, California, U.S.A.) and Implications for Conservation and Management. Conference Proceedings. Springfed Wetlands: Important Scientific and Cultural Resources of the Intermountain Region.

Erman N. A. \& Erman D. C., 1995 - Spring permanence, Trichoptera species richness, and role of drought. Journal of Kansas Entomology Society, 68: 50-64.

Fischer J., Fischer F., Schnabel S., Wagner R. \& Bohle H.-W., 1998 - Die Quellfauna der Hessischen Mittel- gebirsregion. In: Studies in crenobiology. The biology of springs and springbrooks. Botosaneanu L. (ed.). Backhuys Publishers: 183-199.

Galassi D. M. P., 1997 - Little known harpacticoid copepods from Italy and description of Parastenocaris crenobia n. sp. (Copepoda, Harpacticoida). Crustaceana, 70: 694-709.

Girod A., 1965 - Ecologia dei molluschi viventi in un fontanile della provincia di Milano. $1^{\circ}$ contributo alla conoscenza della malacofauna dei fontanili lombardi. Atti della Società Italiana di Scienze Naturali, 104 (1): 69-82.

Gerecke R., 1991 - Taxonomische, faunistische und ökologische Untersuchungen an Wassermilben (Acari, Actinedida) aus Sizilien unter Berücksichtigung anderer aquatischer Invertebraten. Lauterbornia, 7.

Gerecke R., Meisch C., Stoch F., Acri F. \& Franz H., 1998 - Eucrenon-hypocrenon ecotone and spring typology in the Alps of Berchtesgaden (Upper Bavaria, Germany). A study of microcrustacea (Crustacea: Copepoda, Ostracoda) and water mites (Acari: Halacaridae, Hydrachnellae). In: Studies in crenobiology. The biology of springs and springbrooks. Botosaneanu L. (ed.). Backhuys Publishers: 167-182.

Gerecke R. \& Franz H., 2006 - Quellen im Nationalpark Berchtesgaden. Lebensgemeinschaften als Indikatoren des Klimawandels. Nationalpark Berchtesgaden.

Gooch J. L. \& Glazier D. S., 1991 - Temporal and spatial patterns in Mid-Appalachian springs. Memoirs of the Entomological Society of Canada, 155: 29-49.

Harding P. T. \& Sutton S. L., 1985 - Woodlice in Britain and Ireland: distribution and habitat. Institute of Terrestrial Ecology.

Hoffsten P. O. \& Malmqvist B., 2000 - The macroinvertebrate fauna and hydrogeology of springs in central Sweden. Hydrobiologia, 436: 91-104.

Illies J., 1952 - Die Mölle. Faunistisch-ökologiske Untersuchungen an einem Forellenbach im Lipper Bergland. Archiv für Hydrobiologie, 46: 424-612.

Ilmonen J. \& Paasivirta L., 2005 - Benthic macrocrustaceans and insect assemblages in relation to spring habitat characteristics: patterns in abundance and diversity. Hydrobiologia, 533: 99-113.

Ilmonen J., Paasivirta L., Virtanen R. \& Muotka T., 2009 Regional and local drivers of macroinvertebrate assemblages inboreal springs. Journal of Biogeography, 36: 822-834.

Ilmonen J., Mykrä H., Virtanen R., Paasivirta L. \& Muotka T., 2012 - Responses of spring macroinvertebrate and bryophyte communities to habitat modification: community composition, species richness, and redlisted species. Freshwater Science, 31:657-667.

Laini A., Bartoli M., Castaldi S., Viaroli P., Capri E. \& Trevisan M., 2011 - Greenhouse gases $\left(\mathrm{CO}_{2}, \mathrm{CH}_{4}\right.$ and $\mathrm{N}_{2} \mathrm{O}$ ) in lowland springs within an agricultural impacted watershed (Po River Plain, northern Italy). Chemistry and ecology, 27 (2): 177-187.

Lamberti G. A., Chaloner, D. T. \& Hershey A. E., 2010 Linkages among aquatic ecosystems. Journal of the North American Benthological Society, 29: 245263. 
Latella L. \& Stoch F., 2001 - Biospeleologia. In: Grotte e fenomeno carsico. La vita nel mondo sotterraneo. Stoch F. (a cura di). Quaderni Habitat. Ed. Ministero dell'Ambiente, Museo Friulano di Storia Naturale, 1: 53-87.

Laukötter G., 1993 - Crunoecia irrorata. Portrait einer Köcherfliege der Quellen. Crunoecia, 2: 85-88.

Mac Arthur R. H. \& Wilson E. O., 1963 - An equilibrium theory of insular zoogeography. Evolution, 17: 373387.

Mac Arthur R. H. \& Wilson E. O., 1967 - The theory of Island Biogeography. Princeton University Press.

Maiolini B., Carolli M. \& Silveri L., 2011-Ephemeroptera, Plecoptera and Trichoptera in springs in Trentino (south-eastern Alps). Journal of Limnology, 70 (1): 122-133.

Martin P. \& Brunke M., 2012 - Faunal typology of lowland springs in northern Germany. Freshwater Sciences, 31 (2): 542-562.

Mezzanotte E. \& Sambugar B., 2004 - Contributo alla conoscenza della fauna delle sorgenti. In: Il Monte Pastello. Latella L. (ed.). Monografie Naturalistiche: 283-292.

Moretti G. P. \& Viganò A., 1959 - L'habitat e la biologia di Helicopsyche sperata Me. L. in Toscana. Bollettino di zoologia, 26: 573-589.

Olmi M., 1976 - Coleoptera Dryopidae, Elminthidae. Fauna d'Italia. Edizioni Calderini, 12.

Pesci I., 2010 - Fresh water terrace springs near Pavia: an unusual example of ecological peculiarity. Scientifica Acta, 4 (1): 17-26.

Roca J. R., Ribas M. \& Baguiti J., 1992 - Distribution, ecology, mode of reproduction and karyology of freshwater planarians (Platyhelminthes; Thurbellaria; Tricladida) in the springs of the central Pyrenees. Ecography, 15: 373-384.

Roca J.R. \& Baltanas A., 1993 - Ecology and distribution of Ostracoda in Pyreanean Springs. Journal of Crustacean Biology, 13: 165-174.

Sambugar B., Dessi G., Sapelza A., Stenico A., Thaler B. \& Veneri A., 2006 - Fauna sorgentizia in Alto Adige. Provincia Autonoma di Bolzano.

Sconfietti R., Paganelli D. \& Pesci I., 2009a - Indagini preliminari sulla fauna macrobentonica di microhabitat sorgivi di terrazzo fluviale a Pavia. Studi Trentini di Scienze Naturali, 86: 81-82.

Sconfietti R., Mezzadra M. \& Pesci I., 2009b - La mappa della funzionalità fluviale in un corso d'acqua urbano a Pavia: la roggia Vernavola. In: Acqua e Città Expo 2015. Idraulica e Paesaggio nelle aree urbane. III Convegno nazionale di Idraulica Urbana, Milano.

Smith H. \& Wood P. J., 2002 - Flow permanence and macroinvertebrate community variability in limestone spring systems. Hydrobiologia, 487: 45-58.

Smith H., Wood P. J. \& Gunn J., 2003 - The influence of habitat structure and flow permanence on invertebrate communities in karst spring systems. Hydrobiologia, 510: 53-66.

Steinmann P., 1915 - Praktikum der Süßwasserbiologie. Bornträger.
Stoch F., 2001 - La fauna a invertebrati. In: Risorgive e fontanili. Acque sorgenti di pianura dell'Italia Settentrionale. Minelli A. (ed.). Ministero dell'Ambiente e della Tutela del Territorio e Museo Friulano di Storia Naturale, 2: 63-95.

Stoch F. \& Tomasin G., 2002 - La fauna delle acque carsiche sotterranee del Montello. Speleologia Veneta, 10: 41-70.

Thienemann A., 1922 - Hydrobiologische Untersuchungen an Quellen. Archiv für Hydrobiologie, 14: 151-190.

Vannote R. L., Minshall G. W., Cummins K. W., Sedell J. R. \& Cushing C. E., 1980 - The river continuum concept. Cnadian Journal of Fisheries and Aquatic Sciences, 37: 130-137.

Von Fumetti S., Nagel P., Scheifhacken N. \& Baltes B., 2006 -Fattores governing macrozoobenthic assemblages in perennial springs in north-western Switzerland. Hydrobiologia, 568: 467-475.

Von Fumetti S. \& Nagel P., 2012 - Discharge variability and its effects on faunistic assemblages in springs. Freshwater Sciences, 31 (2): 647-656.

Wagner R., Fischer J. \& Schnabel S., 1998 - The Dipteran community of Central European springs: a summary. In: Studies in crenobiology. The biology of springs and springbrooks. Botosaneanu L. (ed.). Backhuys Publishers: 125-140.

Ward J. V. \& Tockner K., 2001 - Biodiversity: towards a unifying theme for river ecology. Freshwater Biology, 46: 807-819.

Weigand E., 1998 - Limnologisch-faunistische charakterisierung von karstquellen, quellbachen und unterirdischen gewassern nach choriotopen und biozonotischen Gewasserregionen. Nationalpark. Kalkalpen.

Werum M., 2001 - Die Kieselalgengesellschaften in Quellen: Abhängigkeit von Geologie und anthropogener Beeinflussung in Hessen (Bundesrepublik Deutschland). Schriftenreihe Hessisches Landesamt für Umwelt und Geologie.

Wiberg-Larsen P., Brodersen K. P., Birkholm S., Grøn $§$ P.N. \& Skriver J., 2000 - Species richness and assemblages structure of Thricoptera in Danish stream. Freshwater Biology, 43: 633-647.

Whittaker R. J., Willis K. J. \& Field R., 2001 - Scale and species richness: towards a general, hierarchy theory of species diversity. Journal of Biogeography, 28: 453-470. 